STATION PRECISION 450, EasyVIsion

【方法】(1)Navigated B-TFEによって冠動脈を撮影する。(2)得られた画 像に对してSoap-Bubble法を用い冠動脈抽出を行う。(3)EasyVisonを 用い，得られた画像に対してMIP法とMPR法で冠動脈抽出を行う。

(4)劝方により得られた冠動脈西像に対し，血管系・分枝の数を計測 しランキングする。

【結果・考察】底現性・抽出能に执いて, Soap-Bubbleが高得点を示し た。本法は冠動脈のみならず，血管もしくは管腔の抽出に応用が可 能であり，非常に有用なソフトである。

\section{2 乳児・幼坚期の冠動脈描出能の検討}

東京莪信病院放射線科 佐藤恒昭, 武村 濃, 大室正巳 フィリップスメディカルシステムズ(株） 小原 真, 勝又康友 【目的】当院では川崎病疾患の冠動脈描出を2002年 3 月からrealtımenavigatorecho balanced-TFEを用い撮像している。乳児・幼児期の描 出能は10藏以上に比べると低い結果であった。今回この久点を改善 するため检討したので解告する。

【使用装置. PPHILIPS社.製GYROSCAN INTERA MASTER I.5T，SENSE Cardac coil

【方法】従来行ってきたシーケンスのFOV, TFE factor, SENSE factor, delay gatıng, navigator windowを変化させて, 従来法との描 出能を比較娭討した.

【対象】2002华 3 月から2003华 5 月までの川崎病患䍐95侧。内訳は 0

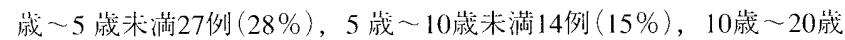
未满 35 例 (37\%)，20藏以上19例 $(20 \%)$ であり, 平均华㱓8.6嵗(4 个 月 27 藏) .

【結果】今までは，10歳以上と同じシーケンスで検査を行っており，描 出能は低かった。今回行った検討により，それぞれの設定值を変える 事で描出能の低かった乳巟・幼児期の描出能の向上が図られた。

\section{Black Blood法による川崎病冠動脈瘤内評価}

東京我信病院・放射線科 武村 濃, 佐藤恒昭, 大室正上

フィリップスメディカルシステムズ(株）小原 真, 勝又康友

【目的】当院では川崎病疾患の冠動脈のフォローアップにMR装置を 朋いて行っている。従来は心電同期・呼吸同期併用3D balanced TFE （以下b-TFE）を用いて冠動脈の描出を高信号に描出していた。今 回，心電同期 - 呼吸同期併用M2D Black Blood法(以下BB法) 老付け 加之冠動脈描出を行いb-TFEとの描出の相違を検討した。

【対象と方法】フィリップス社製Gyroscan Intera1.5TでMR Coronary Anglography (以下MRCA) を行った川崎病冠動脈障害の95症例中12例 (1 蔵から 24藏, 男性 8 例, 女性 2 例 平均10.3藏)にBlack Blood法 を行った。シーケンスは $3 \mathrm{D}$ b-TFE (TR/TE $=4.1 / 2.0 \mathrm{~ms}, \mathrm{FA}=80^{\circ}$, FOV $=250 \sim 350 \mathrm{~mm}$, slice $\mathrm{Th}=15 \mathrm{~mm})$ とM2D-Black Blood法 $(\mathrm{TR} /$ $\mathrm{TE}=2$ beats $/ 26 \mathrm{~ms}, \quad \mathrm{FA}=90^{\circ}, \mathrm{FOV}=250 \sim 350 \mathrm{~mm}$, slice $\mathrm{Th}=3.0 \mathrm{~mm}$ )であ る。相シーケンスとも心電同期，呼吸同期併用で行った。

【絬果】b-TFEでは任流信号を高信昘に，BB法では血流信号を抑制し て低信号に描诎する。しかし，冠動脈瘤内の描出に違いが出た。双 方のシーケンスを用いることにより，MRCAでの川崎病冠動脈瘤内 䚵怵が行えることを知った。

\section{MR心臓画像解析ソフトの開発}

東海大学医学部付属病院・放射線技術科松尾太一, 室伊三男 堀江朋彦，木村絵里，花木 昭

【目的】近华MRL臟検查の有朋性が，多数報告され，臨床でも增加 している。しかし，その画像を定量的に解析するものや，視覚的観 察を容易にする解析ソフトの普及が，核医学や超音波など，他のモ ダリティにくらべ遅れているように思う。今回は，その心臓MRI画 像に扔ける解析ソフトの開発㧍よび，その必要性について検討した
ので韩告する。

【方法】自作の心臓内腔自動輪郭抽出ソフトにより, すべての画像に 対して心臓内腔を抽出する。各洔相の画像在スライス方向に対して 補間し，時相に対寸る心臓のボリュウムの変化を求める。また将相

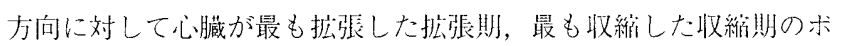
リュウムから, EFを求めるという作業を行う。つぎに, 半自動的に 心臓の内腔を抽出する垷存のソフトで, ホリュウムの変化, EFを求 める作業を行う。その耐者の你業洔間, またオペレーターによる做 人善を比較する。

【結果】自動抽出が可能になることで, 解析時問を大幅に短䋊するこ とができままた解析を行うオペレーターの判断による個人箇を少な くすることができた。

【結諭】今後, 心臟MRI検査が普及するにあたって，その画像を短時 間で正確に解析できる高度な解析ソフトの普及が望まれる。

305 心筋 ${ }^{31}$ P-MRSの臨床応用に向けた基礎的検詂(第 2 跟) 東北大学医学部附属病院放射線部永坂竜男, 山中一臣、松崎智子 渡邊浩幸, 中村大介，梁川 功，佐々木正寿

東北大学医療技術短期大学部・診療放射線技術学科千田浩一

【目的】1P-MRSは心筋エネルギー代謝の非侵襲的媩洒法として, 特 に虚血性心疾腎に対して有用といわれているが，S/Nが低く施行時 間が長いなどの理由から心疾患患者への適応が難しく㶾床には普及 していない。これまでわれわれはCSI法を使用した心觔 ${ }^{31}$ P-MRSの嵒

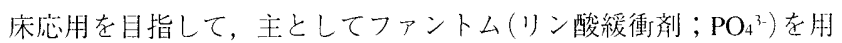

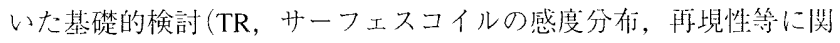
する詊価)を行ってきた、今回，CSI法のphase encoding と積算回数を 変化させ，心筋 ${ }^{31} \mathrm{P}-\mathrm{MRS} の$ 施行時䦎を短縮した方法を考案しその有 用性について検討したので報告する。

【方法】臨床用MRI装置であるSiemens社製MAGNETOM Vision 1.5Tお よび $\mathrm{H} /{ }^{\beta} \mathrm{P}$ 二重共鳴サーフェスコイルを使用した。位狊決め用の 3 方 向のMRI撮像後, マルチボクセル2D-CSI法 ( Z軸スライス選択=3D デー夕取集領域選択)による ${ }^{31} \mathrm{P}-\mathrm{MRS}$ を行った。標準法(16×16 phase encoding, 積算 8 , 施行時問約 32 分), 短時問法 $1(8 \times 8$ phase encodıng, 積算. 4 , 施行時間約 4 分) と短時間法 2 ( $16 \times 16$ phase encoding, 積算 1 , 施行時閒約 4 分)について, ファントムにおける 再垷性, S/N (FID-sıgnal)の評価と, 正常ボランティアによる心筋代 謝産物の信号強度, 再現性について倹討を行った。

【結果】短時間法1のファントム执よび正常ボランティアの再現性は 良好であり，またスペクトルの形状拉よび $\mathrm{S} / \mathrm{N}$ 標準法と同等で あった。短時問法 2 は, ノイズが多く再現性は到かった。

【結論】 ${ }^{31} P-M R S$ 短時間法 1 は, 心疾患患者の臨床に使朋できる可能 性が有る事が示唆された。

306 Microscopy coilを用いたMR-Mammary Ductgraphy (基礎編) 聖マリアンナ医科大学病院・画像診断センタ一馬野清次, 小川泰良 吉田和良, 成松 洋, 佐藤光也

【目的】近年のMR装置開発の中，更なる高分解能西像を得るべく Microscopy colが誕生した，今国われわれはそれを乳腺領域に用い， 今まで成し得なかったMR-Mammary Ductgraphyの実現を目的とし， 臨床に扔いて有用な情報を得るべく基礎的倹討を行ったので報告を する。

【使用装置・機器】PHILIPS社製Gyroscan NT Intera / Master1.5T, Coil : Microscopy coll (47mm $\phi)$, Phantom : CuSO4水溶液 · CT 用空閏 分解能測定用Phantom · 自作Contrast测定用Phantom

【方法】(1感度分布：CLEAR法の有無による感度分存の遌いを検討 する. (2) 空閏分解能: CT 用Phantomを用い空閣分解能の测定を行 う。 (3) Contrast：臨床に扮いてMIX法を用いて乳腺組織のT1，T2值 を得る、結果より撮像Sequenceを定め自作Phantomにおいて検討亦 
る.

【結果】(1) CLEAR法を用いた方が明らかに良好な感度分布を得るこ とができた。また，FOVは70×70mm程度が妥当だと考えた。(2)

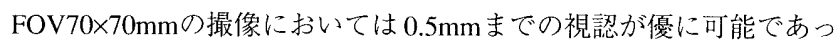
た. (3) MIX法では, 乳腺の平均T1值は1000, T2値は100であった. 結果よりT1およびT2強調画像の撮像を自作Phantomにて行ったとこ ろ，ともに良好なContrastの画像が得られた。

【まとめ】Microscopy collを用いCLEAR法を併用することで, 高分解 能かつ良好なContrastの画像を得ることができた。定めたSequenceを 使用することでMR-Mammary Ductgraphyは現実のものとなり, 臨床 に执いて有用な情報が得られるものと考える。

307 Microscopy coilを用いたMR-Mammary Ductgraphy(臨床編) 聖マリアンナ医科大学病院・画像診断センター 小川泰良, 馬野清次 吉田和良, 成松 洋, 佐藤光也

【目的】Microscopy Coilの開発によって, 高分解能画像を得ることが 可能となり，乳腺領域に扔いて基礎的検討をした結果，MRMammary Ductgraphyの可能性が示唆された，そこでわれわれは，基 礎編にて定めたSequenceを臨床に用いて検討を行い，さらに従来の 乳管造影との比較を行ったので報告する.

【使用機器】装置：PHILIPS社製 GYROSCAN NT Intera/Master1.5T, Coil : Microscopy coil $(47 \mathrm{~mm} \phi)$, 自作固定台

【方法】基礎編にて定めたSequenceを用い，乳管の描出や各組織の信 号強度等について検討した。 また, MRI施行後に従来の乳管造影を 行い，手術が行われた症例は病理所見も対比した.

【結果抒よび考察】多数の症例に扔いて，末梢枝まで良好な Ductgraphyを得ることが可能であった。 また, 経静脈性にGd-DTPA を用いると，微小な乳管内病変の存在や，その進展を把握する事が できた、乳管の信号強度はTIWI画像で高信号を呈したが，T2WI画 像においても高信号を呈するものがあり，乳管内容物の違いによっ て正常乳腺とのコントラストが変化するため，2 種類のSequenceを 用いることが重要と思われる. 拡張している乳管が描出でき, 病変 部より末梢枝の乳管も明瞭に観察可能である M R - M a m m a r y Ductgraphyは臨床的に有用であり, 従来の乳管造影に比へ，低侵襲 (乳頭に針を刺入しない, 被ばくがない等)の点においても優れた検 査法であると考える.

308 乳腺dynamic MRIにおけるパラメトリック画像表示の検討 千葉県がんセンター・画像診断部 小原信也，藤ヶ崎香里，中島英樹 種山英記，横山孝徳，牧本裕美，高野英行

【目的】平成14年 1 月から MRI装置更新に伴い, MR mammographyが 行えるようになった。今回われわれは, dynamic studyによる Enhancement curve解析の結果をパラメトリック画像表示させること で，進展範囲をより明瞭に表示させることができないか検討したの で報告します。

【方法】使用装置は，GE横河メディカルシステム社製SIGNA MR/1 Echospeed 1.5Tである. 使用coilは, Open Breast Array coilで, 撮像 方法は, 3D-Fast SPGR, TR : minimum, TE : 2.1/Fr msec, TI : 40msec, flip angle : 20, 1NEX, matrix :256×160にて 1Phase 30secで

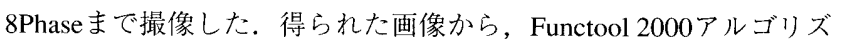
ムのうち, Signal Enhancement Ratio, Maximum Difference Function, Positive Enhancement Integral 用いて, Thresholdを30，40，50，60, 70 まで変化させてパラメトリック画像表示させた。

【結果】time-Intensity-curveに則ったカラー表示画像を作成でき，その 形態学的な特徴は鑑別診断の補助として役立った。

【結論】1. ROIによる解析よりも進展範囲を明瞭に把握できた. 2. 腫瘍構造がより明瞭になった。
309 春䯣撮像における3D-FIESTAの検討

北見脳神経外科病院. 診療技術部放射線科 白方正道, 長岡政勝 石川泰也，高橋美希，佐々木康二，高橋剛史，田頭剛弦

【目的】1.5TMRI装置の増設(平成14年 9 月)に伴いさまざまなパルス シーケンスが選択可能となった。 そこで今回SteadyStateのパルス シーケンスであるFIESTAを使用した脊䯋撮像法の特徴と有用性を探 るべく検討したので報告する。

【方法】1 各脊髄において撮像時間を考慮し3D-FIESTAの最適条件を

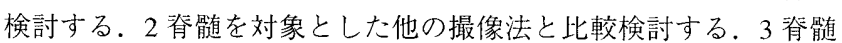
疾患において三次元的画像表示法を用い神経根の描出を試みる。

【結果】フィリップ角を上げると脊髄の信号は上昇するが撮像時間 も長くなる．当院の検查状況，および患者負担を考えると 45 度程度 が最適と思われた。また，頸髄から腰髄までを同一条件で撮像する と頸髄と上部胸髄でバインディングアーチファクトが発生した. 2 他の撮像法に比べてthinsliceの3Dで撮像しているため, 撮像後に MPR処理で任意の方向から画像を作成する事ができた。 3 脊髄へル ニアにおいてVolumeRenderingやVirtualEndoscopy等を用い三次元的 に神経圧迫の状態を確認する事ができた。

【考察】バインディングアーチファクトの原因はFOV内に磁化率の異 なる空気の存在が考えられる。その対策として頸髄や上部胸蕆では シミングだけ空気成分の入らないようにFOVを狭くし，TRも最短に なるような条件を設定しアーチファクトを低減させている。また, 他の撮像法に比べて任意の方向から画像の作成が可能である為, 脊 髄の側弯した場合に有用であると考えられた。

【まとめ】今回の検討から当院では春髄疾患が疑われる患者におい て, 比較的短時間で十分な情報が得られる3D-FIESTAを外来スク リーニングとして使用している，今回は脊髄に限定して検討を行っ たがコイルに依存するシーケンスではない為, さまざまな部位での 応用が可能であると期待された。

310 Moving Table MR imaging systemによるWhole body MR Imagingの評価

聖隷三方原病院 - 総合画像診断部 野沢泫幸, 天野智康, 長屋重幸 太田達也，中野 仁，窪田一十

【目的】Moving Table MR imaging system(research sequence)は, テーブルを移動させながらデータ収集を行う為, 一度の acquisitionにて頭 頂部から足底部の領域をカバーすることができる新しい撮像法であ る。われわれは, Moving Table MR imaging systemに於ける撮像条件 を検討し，転移性春髄腫瘍疾患への臨床応用を行った。

【方法】MRI装置はGE社製1.5T Signa Horizon LX, Body Collを使用. 1. 使用可能パルスシーケンス gradient echoのイメージングパラメー 夕についてファントム実験拈よびボランティアを募り検討した。 パ ラメータ : TR (14.2 10000), TE (6.9 1000), Flıp Angle (0〜180 度), Over lap $(0 \sim 100 \%)$. 2. 転移性脊随腫瘍疾患に臨床応用した。 【結果】現時点で使用できるパルスシーケンスでは，GRASS法による 画像が良好であった. 撮像条件は, TR/TE/FA= $14.3 \mathrm{~ms} / 6.9 \mathrm{~ms} / 70^{\circ}$ で あった，撮像に要する時間は, sagittal像では, $10 \mathrm{mmth}, 7$ 断面で $4 \mathrm{~min} 42 \mathrm{sec}$, coronal像では, $12 \mathrm{mmth}, 15$ 断面で $4 \mathrm{~min} 35 \mathrm{sec}$ であった. なお，撮像範囲は約 $170 \mathrm{~cm}$ であり，十分に全脊椎をカバーすること ができ転移性脊髄腫瘍疾患の評価には有用であった。しかし, 本法 にて使用できるパルスシーケンスが限られたものである為, 臨床応 用ではあくまでも付加的な位置づけに留まってしまう。今後，パル スシーケンスのバリエーションが豊富になれば，臨床応用できる領 域は拡大される。 